\title{
EFFECT OF GAMMA IRRADIATION ON CELLULASE ACTIVITY OF PLEUROTUS PULMONARIUS DURING THE DIFFERENT GROWTH STAGES ON DIFFERENT PLASTIC POLYETHYLENE WASTES
}

\author{
Hashem,B.M.I. ${ }^{\text {; }}$ EL-Beih,F.M. ${ }^{\text {; }}$ Abd El-Aziz,S.M. ${ }^{2}$ Easanin,S.M. ${ }^{\text {; }}$ EL-Halby,H.E.E.T. ${ }^{3}$ \\ ${ }^{1}$ Microbiology department,Faculty of Science, Ain shamsUniversity,Egypt \\ ${ }^{2}$ Radio-Biochemistry, Atomic EnergyAuthority, Egypt \\ ${ }^{3}$ Microbiology department, Middle Eastern Regional Radioisotope center for the Arab Countries, Egypt.
}

\begin{abstract}
Pleurotus pulmonarius was excellent growth on determined weights of the wet rice straw, non irradiated plastic, irradiated plastic, mixture of rice straw and non irradiated plastic and mixture of rice straw and irradiated plastic. maximum value of cellulase recorded on rice straw, mixture of rice straw and irradiated plastic, mixture of rice straw and non-irradiated plastic (1.7, 1.5 and 1.3 unit/gm waste), respectively, which recorded after first harvest; but irradiated plastic and non-irradiated plastic giving highest values at promordium stage; (1.14 and 0.79 unit/gm waste).

The spawn of P. pulmonarius was irradiated at the does 0.5, 1 and $2 \mathrm{KGy}$, and inoculated on each different wastes separately to detect the cellulase activity which was increased in the various wastes by exposing the spawn of P. pulmonarius to gamma irradiation and detectable raises in the cellulase activity was recorded at dose $0.5 \mathrm{KGy}$, Any further increase in the irradiation dose was accompanied by a decrease in cellulase activity until reach lowest value at 2 KGy.
\end{abstract}

\section{INTRODUCTION}

Accumulation of plastic waste in the environment causes wide scale pollution with long lasting effects making plastic waste management expensive and problematic (Zafar et al. 2013). Yang et al. (2007) reported that plastic material is one of the most serious solid wastes pollution and it's accumulation in the environment is highly resistant to biodegradation and is not able to take part in substance recycle.

Microorganisms utilize polyethylene film as a sole carbon source.These bacteria colonize the polyethylene surfaces forming a biofilm. Cell surface hydrophobicity of these bacteria was found to be an important factor in the formation of biofilm on the polyethylene surface(Orhan et al. 2004). Mushrooms are being explored in new ways. That is; they are being used to break down previously harmful materials such as oil and plastic (Gruber, 2009)

Exoenzymes from the microorganisms first breakdown the complex polymers giving short chains or monomers that are small enough to permeate through the cell walls to be utilized as carbon and energy sources (Premraj and Dobley, 2005). Enzyme systems in mushroom have the ability to degrade cellulose, hemicelluloses and lignin by the cleaveing of lingo (hemi) cellulosic bonds or through lignolysis (Neelakantan et al., 1993). Awang et al.(1998) reported that Pleorotus sajor-caju and Coprinus cinereus can be easily grown on empty fruit bunch and degraded lignocellulosic material by the ability of cellulase enzyme system to break down insoluble cellulose, and hydrolysing salicin such as cellobiose and xylanase for breaking down hemicellulose into simple sugars.

Earlier works have reported that gamma-ray irradiation on various lignocellulosic biomasses such as bagasse (Kumakura and Kaetsu, 1983), rice straw and sawdust (Bhatt et al., 1992) were effective to improve enzymatic saccharification rate. All the gamma irradiation were effective in retarding mushroom sensory deterioration jiang et al. 2010).

Benoît et al. (1999) reported that ionizing treatments of edible mature mushrooms (Agaricus bisporus, albidus) increase significantly the phenylalanine ammonia-lyase, polyphenol oxidase activity and total phenols concentration compared to non irradiated control samples. Dawoud (2012) noted that Gradual gamma irradiation $(0.5$ and $1.0 \mathrm{kGy})$ on genus Pleurotus significantly enhanced high growth, biomass yield, 
Hashem,B.M., et al.

$1,3-\beta$-glucan production and carbon metabolites contents, glucose absorption, 1,3- $\beta$-glucan synthase activity and protein content. On the other hand, these low irradiation doses inhibited the accumulation of cellular and extracellular keto acids, free ammonia, extracellular 1,3- $\beta$-glucan permeation Dawoud (2012).

\section{MATERIALS AND METHODS}

\section{Plastic polyethylene wastes}

In the present study, plastic polyethylene based wastes stimulates (namely; non irradiated and irradiated plastics) and rice straw were used. In the meantime, equal weights of all waste simulates were mixed together to form the mixture category of the waste simulate. Substrate of rice straw was used to serve as control treatment

\section{Used mushroom}

The biological treatment of the stated solid waste simulates were performed using Pleurotus pulmonarius (Somy cel 3014, France), This strain was kindly obtained from Agricultural Research Centre, Cairo, Egypt. This strain was obtained as mycelia on $2 \%(\mathrm{w} / \mathrm{v})$ malt extract with $1.5 \%(\mathrm{w} / \mathrm{v})$ agar media. Plate cultures were prepared for the subsequent work.

\section{Preparation of spawn: -}

Wheat spawn was prepared, as described by Chang(1982), as follows: In flask $250 \mathrm{ml} \mathrm{ca}-$ pacity, $50 \mathrm{~g}$ of wheat grains were added to one $\mathrm{g}$ limestone chalk dissolved in $75 \mathrm{ml}$ distilled water. Three equal sets were prepared each was composed of six flasks and autoclaved . Each sets was inoculated with disc (one $\mathrm{cm}$ diameter) of Pleurotus pulmonarius separately, and incubated at $26 \pm 2{ }^{\circ} \mathrm{C}$ for 15 days.

\section{Biodegradation of Plastic polyethylene wastes biologically using Pleurotus pulmonarius:}

Determined weights of the wet rice straw, non irradiated, irradiated plastics and the mixture of equal ratios of these wastes were mixed with $4 \%(\mathrm{w} / \mathrm{w})$ of wheat bran and calcium carbonates. Three sets of each waste were then inoculated with the spawn of P. pulmonarius. (Chang 1978). The spawned waste was then transferred separately to suitable polyethylene clean bags. The inoculated plastic bags of all wastes were incubated at temperature ranged from $20-25^{\circ} \mathrm{C}$ until the mycelia of mushroom have got luxurious growth. Then each bag was opened by tearing to let the fungal growth completed to the fruiting stage.

\section{Gamma irradiation of spawn:}

To enhance the capability of the microorganism for the degradation of plastic polyethylene wastes (non irradiated, irradiated) at the end of incubation period, six spawn replicates of $P$. pulmonarius were irradiated at different doses namely $(0.5,1,2$ kilo Gray) in gamma radiation cobalt-60 cell at dose rate $1.56 \mathrm{~Gy} / \mathrm{min}$ (EI-Sayaad 2008). Other set of flasks were not irradiated and used as control. Irradiated and non-irradiated spawn were inoculated separately on the different wastes categories (rice straw, non irradiated, irradiated plastics and their mixture) as indicated previously. Then the determinations of enzymes were done.

\section{Preparation of crude enzymes:-}

The plastic bags containing different plastic polyethylene wastes were inoculated with irradiated and non-irradiated Pleurotus pulmonarus spawn and were incubated at $20-25^{\circ} \mathrm{C}$. During the mycelia growth, cellulase activity were assayed spectrophotometerically after $(3,6,9,12$, $15,18)$ days of inoculation, at primordia phase, at the beginning of sporophorore formation, and after the first harvest directly.

Tri plicate, each $50 \mathrm{~g}$ of the bags containing the mycelia colonized on the wastes (rice straw, non irradiated plastic, irradiated plastic and their mixture) were removed periodically as previously stated. Each sample was then mixed with $50 \mathrm{ml}$ of $0.01 \mathrm{M}$ phosphate buffer $(\mathrm{pH} \mathrm{7})$ and shacked using vortex at $80 \mathrm{rpm}$ for 20 minute, the mixture was squeezed through several layers of cheese cloth and the filtrate was further clarified by centrifugation at $10,000 \mathrm{rpm}$ for 20 min. at $-4^{\circ} \mathrm{C}$ using Sigma $2 \mathrm{k} 15$-USA centrifuge. The resulting clear supernatants were stored at $-10^{\circ} \mathrm{C}$ before being used for all subsequent assays ( Wood and Goodenough, 1977) then a known weight of ammonium sulphate (5 gm) was added gradually with shaking to measure supernatant until it completely was dissolved to 
bring it to $85 \%$ saturation then left in refrigerator over night, after that the precipitate was dissolved in $1 \mathrm{ml}$ buffer phosphate $(0.01 \mathrm{M}, \mathrm{pH} 7)$, then it transferred in dialysis bag for one hour in distal water for three time then for half hour in buffer phosphate $(0.01 \mathrm{M}, \mathrm{pH} 7)$ to have a sample of protein for enzymatic analysis.

Enzymes Assay:-

\section{Carboxmethyle cellulase activity (CM cellu- lase(:-}

CM cellulase was assayed following Mandels and Rees, 1964, where 250 ul of enzyme extract (suitable dilution of enzyme was used) was mixed with $500 \mathrm{ul} \mathrm{of} 10 \mathrm{mg} / \mathrm{ml}$ sodium salt of carboxymethyle cellulose solution in $0.1 \mathrm{M}$ citrate buffer at $\mathrm{pH} 5$. The mixture was incubated at $50^{\circ} \mathrm{C}$ in water bath with moderate shaking for 30 minutes. Reducing sugars were measured according to Somogyi (1952). The enzyme activity was expressed as ug glucose /g culture.

\section{Somoygi method for determination of the re- ducing sugar:}

\section{Preparation of Somogyi reagent I.}

Anhydrous sodium sulphate $288 \mathrm{~g}$ was dissolved in one liter of boiled distilled water followed by $24 \mathrm{~g}$ Rochelle salt, $48 \mathrm{~g}$ sodium carbonate and $32 \mathrm{~g}$ sodium bicarbonate. The solution was diluted to $1600 \mathrm{ml}$ with boiled distilled water and stored at $27^{\circ} \mathrm{C}$.

\section{Preparation of Somogyi reagent II.}

Anhydrous sodium sulphate $27 \mathrm{~g}$ was dissolved in $300 \mathrm{ml}$ of boiled distilled water followed by $8 \mathrm{~g}$ copper sulphate. The solution was diluted to $400 \mathrm{ml}$ with boiled distilled water and stored at $27^{\circ} \mathrm{C}$.

\section{Preparation of Nelson reagent.}

Ammonium molybdate ( $100 \mathrm{~g}$ ) was dissolved in 1.8 liter of distilled water, followed by $84 \mathrm{ml}$ conc. $\mathrm{H}_{2} \mathrm{SO}_{4}$ and $12 \mathrm{~g}$ sodium arsenate dissolved in $100 \mathrm{ml}$ distilled water was added to the mixture. The mixture was stored at $37^{\circ} \mathrm{C}$ for $24-84$ hour in dark glass bottle at room temperature (El-sayaad 2008).

\section{Reducing sugars assay:-}

$2 \mathrm{ml}$ sample consisting of 4 volume of So- mogyi reagent I and one volume of Somogyi II (mixed immediately before use) was pipette into $15 \mathrm{ml}$ tube along with the sample solution containing reducing sugar and completed with distilled water to give a total volume of $4 \mathrm{ml}$. The solution was boiled in water bath for $15 \mathrm{~min}$, cooled and $2 \mathrm{ml}$ of Nelson reagent. The solution was mixed carefully using vortex mixer. Finally $4 \mathrm{ml}$ of distilled water was added and the solution was mixed by inversion. The absorbance was measured at $540 \mathrm{~nm}$ and then translated into glucose equivalent using standard graph obtained by plotting microgram glucose against absorbance. Determination were carried out using photometric colorimeter APEL(AP - 101).

\section{Statistical analysis:}

The statistical analysis was carried out using F- test two way followed by Duncan's multiple range test. The level of statistical significance was set at $\mathbf{P} \geq \mathbf{0 . 0 5}$.

\section{RESULTS}

Pleurotus pulmonarius has excellent growth on determined weights of the wet rice straw, non irradiated plastic, irradiated plastic, mixture of rice straw and non irradiated plastic and mixture of rice straw and irradiated plastic under different gamma irradiation doses in different stages. Table (1) illustrate the CM-cellulase activities (calculated by unit /g dry waste) for non -irradiated and irradiated P. pulmonarius cultivated on the different wastes ( rice straw, mixture of rice straw and irradiated plastic, mixture of rice straw and non-irradiated plastic, irradiated plastic, non -irradiated plastic). The non-irradiated spawn of $P$. pulmonarius produced the maximum values of cellulase activity after the first harvest directly $(1.7,1.5$ and 1.3 unit/gm waste on rice straw, mixture of rice staw and irradiated plastic, mixture of rice straw and non- irradiated plastic but irradiated plastic and non-irradiated plastic giving highest value after promordium stage respectively(1.14, 0.79 unit/gm waste). The fungal cellulase enzyme was detected during cultivation of $P$. pulmonarius, the spawn of which was irradiated at the dose $0.5,1$ and $2 \mathrm{KGy}$, and inoculated on each different wastes separately.Table (1) illustrates the variation in cellulase activity of $P$. pulmonarius during the 
different incubation periods on various wastes simulates inoculated by spawn exposed to different doses of gamma radiation. The cellulase activity was increased in the various wastes by exposing the spawn of P. pulmonarius to gamma irradiation. Based on the data stated in Table (1), it could be also stated that the CM-cellulase activity was increased at dose $0.5 \mathrm{KGy}$ than other doses recorded 2.1, 1.8, 1.6, 0.76 and 0.3 units/ $\mathrm{g}$ dry waste respectively for rice straw, , mixture of rice straw and irradiated plastic, mixture of rice straw and non-irradiated plastic, irradiated plastic, non- irradiated plastic. Any further increase in the irradiation dose was accompanied by a decrease in the enzyme contents to reach $1.5,1.4,1.16,0.36$ and 0.31 units/g dry waste at irradiation dose of $2 \mathrm{KGy}$ for mixture of rice straw and irradiated plastic, rice straw, mixture of rice straw and non- irradiated plastic, irradiated plastic and non- irradiated plastic respectively. However, it should be mentioned that, the CM-cellulase activities for both irradiated and non-irradiated spawn of $P$. pulmonarius reached to maximum activity after the first harvest phase for all substrate degraded (Table1).

Analysis of variance (F-test) two- way classifications of cellulase activity for doses of gamma irradiation, type of wastes

The statistical analysis using F- test two way in Table (2) illusrated that the variation in cellulase was significant for doses of gamma irradiation and types of wastes. Duncan analysis showed that there was significant value between rice straw, non-irradiated plastic, irradiated plastic, mixture of rice straw and non-irradiated plastic and mixture of rice straw and irradiated plastic,

Table (1): The variation in cellulase activity of $P$. pulmonarius during different incubation periods on various waste simulates after exposing their spawn to different doses of gamma irradiation.

\begin{tabular}{|c|c|c|c|c|c|c|c|c|c|c|c|}
\hline \multicolumn{12}{|c|}{ Cellulase activity (U/g) } \\
\hline \multirow[b]{3}{*}{ waste } & \multirow[b]{3}{*}{ Dose(KGy) } & \multicolumn{10}{|c|}{ Incubation period } \\
\hline & & \multicolumn{6}{|c|}{ Mycelial stage } & \multicolumn{2}{|c|}{ Promordial stage } & \multicolumn{2}{|c|}{ Fruiting stage } \\
\hline & & $\begin{array}{l}\text { ñ } \\
\frac{1}{0} \\
m\end{array}$ & $\begin{array}{l}\frac{n}{2} \\
0 \\
0\end{array}$ & $\begin{array}{l}\frac{n}{7} \\
\frac{\pi}{0} \\
\sigma\end{array}$ & 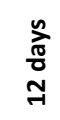 & 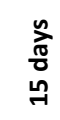 & $\begin{array}{l}\text { ñ } \\
\text { तo } \\
\infty \\
-1\end{array}$ & 5 & $\stackrel{N}{\vdots}$ & ت्1 & $\mathbb{N}$ \\
\hline \multirow[b]{4}{*}{ Rice Straw } & Control & 0.54 & 0.77 & 0.78 & 0.79 & 0.91 & 0.98 & 1.08 & 1.3 & 1.7 & 1.4 \\
\hline & 0.5 & 0.65 & 0.79 & 0.8 & 0.86 & 0.91 & 1.03 & 1.2 & 1.27 & 2.1 & 1.5 \\
\hline & 1 & 0.57 & 0.69 & 0.71 & 0.87 & 0.95 & 0.99 & 1.01 & 1.5 & 1.68 & 1.49 \\
\hline & 2 & 0.43 & 0.67 & 0.69 & 0.76 & 0.83 & 0.91 & 0.96 & 1.1 & 1.4 & 1.3 \\
\hline \multirow{3}{*}{$\begin{array}{c}\text { Non- irradiated } \\
\text { plastic }\end{array}$} & Control & 0.15 & 0.16 & 0.27 & 0.33 & 0.46 & 0.53 & 0.62 & 0.79 & 0.65 & 0.33 \\
\hline & 0.5 & $\frac{0.17}{0.14}$ & $\begin{array}{ll}0.18 \\
0.19\end{array}$ & $\frac{0.26}{0.24}$ & $\frac{0.3}{0.38}$ & 0.37 & 0.49 & 0.51 & 0.57 & $\frac{0.3}{0.34}$ & $\frac{0.11}{0.12}$ \\
\hline & 2 & 0.16 & 0.17 & 0.21 & 0.25 & 0.31 & 0.46 & 0.47 & 0.47 & 0.31 & 0.17 \\
\hline \multirow[t]{4}{*}{ Irradiated } & Control & 0.17 & 0.16 & 0.19 & 0.22 & 0.37 & 0.4 & 0.49 & 1.14 & 0.94 & 0.44 \\
\hline & 0.5 & 0.14 & 0.13 & 0.26 & 0.29 & 0.35 & 0.44 & 0.51 & 1.08 & 0.76 & 0.3 \\
\hline & 1 & 0.14 & 0.17 & 0.2 & 0.29 & 0.36 & 0.4 & 0.48 & 0.96 & 0.66 & 0.29 \\
\hline & 2 & 0.13 & 0.14 & 0.19 & 0.21 & 0.36 & 0.39 & 0.48 & 0.76 & 0.36 & 0.21 \\
\hline \multirow[t]{2}{*}{ Rice Straw and } & Control & 0.24 & 0.33 & 0.38 & 0.4 & 0.42 & 0.44 & 0.45 & 0.55 & 1.3 & 0.67 \\
\hline & 0.5 & 0.37 & 0.36 & 0.41 & 0.5 & 0.53 & 0.59 & 0.7 & 1.25 & 1.6 & 1.5 \\
\hline \multirow{2}{*}{$\begin{array}{c}\text { Non- irradiated } \\
\text { plastic }\end{array}$} & 1 & 0.27 & 0.3 & 0.39 & 0.49 & 0.51 & 0.51 & 0.69 & 0.95 & 1.4 & 1.39 \\
\hline & 2 & 0.26 & 0.27 & 0.31 & 0.44 & 0.49 & 0.53 & 0.56 & 1 & 1.16 & 1.4 \\
\hline \multirow[t]{2}{*}{ Rice Straw and } & Control & 0.26 & 0.29 & 0.37 & 0.45 & 0.48 & 0.55 & 0.81 & 1.09 & 1.5 & 1.06 \\
\hline & 0.5 & 0.29 & 0.33 & 0.41 & 0.52 & 0.65 & 0.74 & 0.86 & 1.1 & 1.8 & 1.5 \\
\hline \multirow{2}{*}{ Irradiated } & 1 & 0.25 & 0.28 & 0.39 & 0.49 & 0.52 & 0.63 & 0.74 & 0.98 & 1.7 & 1.02 \\
\hline & 2 & 0.23 & 0.29 & 0.33 & 0.39 & 0.45 & 0.56 & 0.66 & 0.73 & 1.5 & 0.96 \\
\hline
\end{tabular}

- Cellulase activity expressed by $\mathrm{U}(\mathrm{mg}$ glucose $/ \mathrm{g}$ inoculated fresh substrate

•Promordial stage: included Promordium 1,2(Pr1,Pr2) after $20 \pm 3$ days. •After $1^{\text {st }}$ harvest: afer $25 \pm 3$ days. 
Table (2): ANOVA two way and ducan test analysis for the effect of different types of wastes and doses of gamma irradiation on cellulase activity.

\begin{tabular}{|c|c|c|c|c|c|}
\hline F waste & & \multicolumn{4}{|c|}{$55.711^{*}$} \\
\hline \multirow[t]{3}{*}{ Duncan waste } & $\begin{array}{l}\text { Rice } \\
\text { straw }\end{array}$ & $\begin{array}{l}\text { Non- irradiated } \\
\text { plastic }\end{array}$ & Irradiated & $\begin{array}{c}\text { Rice straw and Non } \\
\text { irradiated plastic }\end{array}$ & $\begin{array}{c}\text { Rice straw and } \\
\text { Irradiated }\end{array}$ \\
\hline & & & & & plastic \\
\hline & c & a & a & b & b \\
\hline F Dose & \multicolumn{5}{|c|}{$2.937^{*}$} \\
\hline \multirow{2}{*}{ Duncan Dose } & Control & $0.5 \mathrm{KGy}$ & $1 \mathrm{KGy}$ & \multicolumn{2}{|c|}{2 KGy } \\
\hline & $a b$ & b & $a b$ & a & \\
\hline
\end{tabular}

*Significant at $\mathrm{P} \geq 0.05$, in each column any two means take the same latter have no significant difference between them by Duncan's multiple range test.

But there was no significant between non-irradiated plastic, mixture of rice straw and non-irradiated plastic, also between irradiated plastic, and mixture of straw and irradiated plastic. Duncan showed significant between different doses and non-significant between control and 1KGy.

\section{DISCUSSION}

Growing of $P$. pulmonarius on the surface of plastic polyethylene wastes.

It was clear from the present study that Pleurotus pulmonarius can grow on the surface of irradiated and non-irradiated polyethylene plastic wastes because it was used as carbon sources which agree with Orhan, et al (2004) who found that microorganisms utilize polyethylene film as a sole carbon source resulting in partial degradation. Other studies have also shown microbial colonization ( Sudhakar,et al 2008), (Chiellini, et al 2007) biofilm formation for Rhodococcus rhodochrous, Cladosporium cladosporoides and Norcardia asteroids ( Bonhomme, et al 2003 ) and the growth of Aspergillus flavus, Penicillium simplicissium and Phanerochaete chrysosporium ( Ojeda et al 2009) in oxo-biodegradable polyethylene.

cellulase activity of $P$. pulmonarius during the mycelial growth and fruiting bodies formation on different wastes (control treatment).

The present part of work was devoted to study the behavior of cellulase secreted by Pleurotus pulmonarius during the growth on the stated polyethylene plastic waste simulates, the cellulase enzyme was measured at different time of growth (mycelia, promordium, fruiting) that because some of them increased by growth time and other were decreased according to behavior of enzyme and substrate content. At the same time, the effect of gamma irradiation pretreatment of the mushroom spawn on the released cellulase of $P$. pulmonarius was evaluated.

It should be stated that, cellulase was represented through 18 days from cultivation, during the primordial formation and after the first harvest. This may be explained on the basis that: during mushroom growth more enzymes were consumed for the degradation of cellulose component, while after the first flushing the enzymes may accumulate with less consumption. In the meantime enzyme production was not the same in the different wastes. The same trend was assessed by Tsang et al. (1987) and Jia et al., 1994 who concluded that cellulase production was varied according to type of waste simulates.

It was reported in the present work that, cellulase activity was increased by increasing the incubation period for non-irradiated spawn of $P$. pulmonarius until reached the highest value at fruiting stage recorded $(1.7,1.5$ and $1.3 \mathrm{U} \backslash$ g) for rice straw, mixture of rice straw and irradiated plastic, mixture of rice straw and non irradiated plastic respectively, but the highest value of cellulase activity for irradiated plastic and non irradiated plastic recorded at promoradia stages (1.14 and $0.79 \mathrm{U} \backslash \mathrm{g}$, respectively) . 
Hashem,B.M., et al.

The difference in activity of cellulase for different substrates could be attributed to the presence of cellulosic substrates (straw) which induce the production of ligninolytic enzymes (Quintero et al., 2006a).

The present study reveled also that the highest net value of cellulose after $1^{\text {st }}$ harvest for $P$. pulmonarius grown on rice straw, mixture of rice straw and irradiated plastic and mixture of rice straw and non irradiated plastic may be attributed to cellulosic materials are a plentiful source of nutrients that favor fungal growth and soil colonization. Additionally, cellulosic substrates induce the production of ligninolytic enzymes (Castillo et al., 2001). Additionally plant residues are a plentiful source of nutrients that favor fungal growth and elicit production of adaptative ligninolytic enzymes (Fujian et al., 2001).

Effect of gamma irradiation on cellulase activity of Pleurotus pulmonarius during the mycelial growth and fruiting on different cellulosic waste simulates.

In the present investigation, cellulase was followed up during cultivating of P.pulmonarius that their spawn were irradiated at the following does; 0.5, 1 and $2 \mathrm{kGy}$, then inoculated on the various plastic polyethylene waste simulate substrates. El-sayaad (2008) observed that irradiation of spawn at dose of $0.75 \mathrm{kGy}$ stimulated the growth rate and activities of extracellular enzymes of $P$. pulmonarius. Lee et al. (2000) reported that gamma radiation induced the fruiting body formation, growth rate and activities of extracellular enzymes of $P$. ostreatus when mycelia were irradiated at doses of 1-2 kGy. Benoît, et al (2000) noted that irradiation at doses of $1.5 \mathrm{kGy}$ and $2.5 \mathrm{kGy}$ reduced significantly the rate of respiration of the mushrooms, compared to that of samples irradiated at $0.5 \mathrm{kGy}$ and nonirradiated control samples.

Data of cellulase activity showed very highly significant increasing by exposure spawn of P.pulmonarius to gamma irradiation at dose 0.5 KGy giving for each wastes respectively; 2.1, $1.8,1.6,0.76$ and 0.3 units/g dry waste for rice straw, mixture of rice straw and irradiated plastic , mixture of rice straw and non-irradiated plastic, irradiated plastic, non- irradiated plastic.
Similar results were obtained by Lee et al.(1999) who stated that, strains of edible mushroom had more highly lignocelluloytic activity after induced by gamma irradiation.

From our study mixture of rice straw and irradiated plastic considered the better waste substrate for P.pulmonarius growth than other wastes because it was giving the highest value of enzyme compared with others. This due to rice straw contains highly nutrition value for mushroom and irradiated plastic was break down by irradiation which may be easier for mushroom consumtion.

\section{CONCLUSIONS}

From this study Pleurotus pulmonarius can grow on plastic polyethylene and use it as nutrient media so that Pleurotus pulmonarius can use as environomental biological treatment from plastic wastes pollution. Cellulase enzyme secreted by high level at fruiting stage on rice straw, mixture of rice straw and irradiated plastic, mixture of rice straw and non- irradiated plastic. Gamma irradiation has effective effect on increasing the ability of mushroom ( $P$. pulmonarius) for growth, enzymes secreation .

\section{REFERENCES}

Awang, M.R. B.; Tamikazu, K. and Shinpei, M. (1998): Preliminary study on isolation and quality analysis of enzymes from fermented oil palm empty fruit bunch. Journal Sains Nuklear Malaysia . v. 16(1) p. 107-117.

Benoît , M.A; D’Aprano, G; ; and Lacroix ,M. (2000): Effect of gamma-irradiation on phenylalanine ammonia-lyase activity, total phenolic content, and respiration of mushrooms (Agaricus bisporus). J Agric Food Chem. 48(12):6312-6.

Benoît, M.A.; D’Aprano, G; Lacroix, M. (1999): Effect of gamma-irradiation on phenylalanine ammonia-lyase activity, total phenolic content, and respiration of mushrooms (Agaricus bisporus). J Agric Food Chem. 48(12):6312-6.

Bhatt, A.K.; Bhalla, T.C.; Agrawal, H.O. and Sharma, N. (1992): Effect of gamma irradiation pretreatment on biodegradation of forest lignocelluloses by Aspergillus niger, Biotechnol. Tech., 6, 111-114.

Bonhomme, S.; Cuer, A.; Delort, A.-M.; Lemaire, J.; Sancelme, M., and Scott, C. (2003): Environmental biodegradation of polyethylene. Polymer Degradation and Stability. 81: 441-452.

Castillo, M., A. Andersson, P. Ander, J. Stenström, and L. Torstensson. (2001): Establishment of the white rot fun- 
gus Phanerochaete chrysosporium on unsterile straw in solid substrate fermentation systems intended for degradation of pesticides. World Journal of Microbiology and Biotechnology 17:627-633.

Chang, S.T. (1978): Volvariella volvacea, the Biology and Cultivation of Edible Mushrooms. Academic Press, New York, , 573-603.

Chang, S.T.(1982): Mushroom Spawn. In Topical mushroom. In : Biolgical nature and cultivation : methods, Eds. chang, S.T and Quimio, T.H. p:31-46. the Chinese univ. Press, HongKong.

Chiellini E, Corti, A. and D'Antone S (2007): Oxo-biodegradable full carbon backbone polymers - biodegradation behaviour of thermally oxidized polyethylene in an aqueous medium. Polym Degrad Stab 92: 1378-1383.

Dawoud, M.E.A. (2012): Participation of different gamma irradiation techniques, doses and radioprotective compounds upon carbon metabolism, polypeptide upregulation and subsequent 1,3--glucans over-production by Pleurotus ostreatus mushrooms. Food. Agr. Envir.,J. 10(1): 235-244. 2012.

El-Sayaad, H.(2008): Effect of gamma radiation on the growth and metabolism of Peurotus ostreatus. Phd Botany department, Fac. of science, Tanta Univ., Egypt.

Fujian, X., C. Hongzhang, and L. Zuohu. (2001): Solid-state production of lignin peroxidase (LiP) and manganese peroxidase $(\mathrm{MnP})$ by Phanerochaete chrysosporium using steamexploded straw as substrate. Bioresource Technology 80:149-151.

Gruber,A.C.(2009): Mushrooms Break Down Oil and Plastic in Bioremediation, Biomass Authority, The Dirt on Clean.

Jia, X.C.; Li, X.; Li, L.; Zhang, G.; and Zhang, G.L.(1994): Degradation of cellulose and hemicellulose in the medium of oyster mushroom and changes of allied enzyme activities. Acta-Agriculturae Boreali Sinica, 9: Supplement, 92-95.

Jiang T.; Luo, S.; Chen, Q.; Shen,L.; Ying T. (2010): Effect of integrated application of gamma irradiation and modified atmosphere packaging on physicochemical and microbiological properties of shiitake mushroom (Lentinus edodes). Food Chemistry, DOI: 10.1016.

Kumakura, K. and Kaetsu, I. (1983): Effect of radiation pretreatment of bagasse on enzymatic and acid hydrolysis., Biomass, 3,199-208.
Lee, Y. and Chang, H. (1999): Radiation sensitivity basidiospore and mycelium in Pleurotus ostreatus. Journal of the Korean Nuclear Society . V. 31(3). P. 287-293.

Lee, Y. K.; Chang, H. H.; Kim, J.S.; Kim, J. K. and Lee, K.S. (2000): Lignocellulolytic mutants of Pleurotus ostreatus induced by gamma-ray radiation and their genetic similarities. Radiation physics and chemistery. V.57, P.145-150.

Mandels, M. and Rees, E. T.( 1964): Fungal cellulases and microbial decomposition of cellulosic fibers . Dev. Indust. Microbiol. 5: 5-12.

Neelakantan, K.K.; Sasikumar C. and Venugopalan, R. (1993): A Book of Kerala Birds. World Wide Fund for Nature-India, Kerala StateCommittee, Trivandrum, 146 pp

Ojeda TFM, Dalmolin E, Forte MMC, Jacques RJS, Bento FM, et al. (2009): Abiotic and biotic degradation of oxobiodegradable polyethylenes. Polym Degrad Stab 94: 965-970 doi:10.1016/j.polymdegradstab.2009.03.011.

Orhan, Y.; Hrenovic, J. and Buyukgungor, H. (2004):Biodegredation of plastic compost bags undered controlled soil condations, Acta Chem Slov,(51)579-588.

Premraj, R. and Dobley, M. (2005): Biodegradation of Polymers, Ind. J. Biotechnol. (4) 186-193.

Quintero, J.C., G. Feijoo, and J.M. Lema. (2006a): Producción de enzimas ligninolíticas con hongos basidiomicetos por fermentación en estado sólido. Vitae 13:61-67.

somogyi, M (1952): Notes in sugar determination .j. boil. chem., 195:19-23.

Sudhakar M, Doble M, Sriyutha MP, Venkatesan R (2008): Marine microbe mediated biodegradation of low and high density polyethylenes. Intern Biodeter Biodegr. 61: 203-213.

Tsang, L. J.; Reid, I. D. and Coxworth, E. C. (1987): Delignification of wheat straw by Pleurotus spp. under mushroom growing conditions. Applied-and-Environmental-Microbiology., 53: 6, 1304-1306.

Wood, D. A. and Goodenough, P. W.(1977):Fruiting of Agaricus bisporius. Arch. Microbiol.,114,161-165.

Yano J; Song, Y. L. and Qin, X. Y. (2007): Biodegradation of polyethylene. Huan Jing Ke Xue. 28(5):1165-8.

Zafar, U.; Houlden, A. and Robson, D.G.(2013): Fungal communities associated with the biodegradation of polyester polyurethane buried under compost at different temperatures. Appl. Environ. Microbiol. 
تأثير أشعة جامـا على نثاط إنزيم السيليوليز لفطر عيش الغراب المحارى أثناء مراحل النمو المختلفة على المخلفات البلاستيكية المختلفة

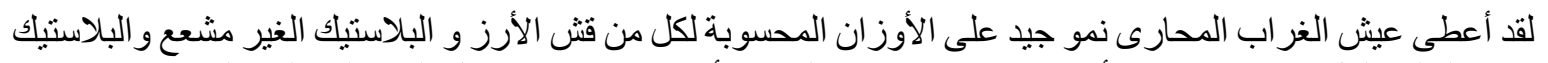

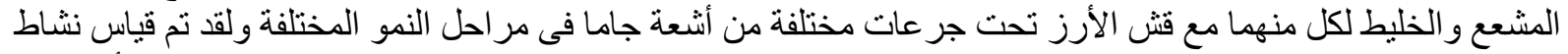

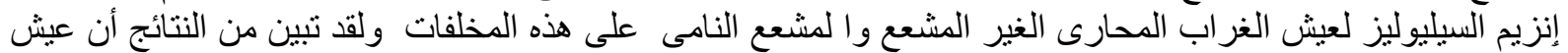

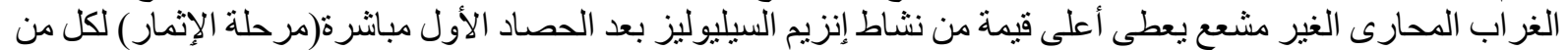

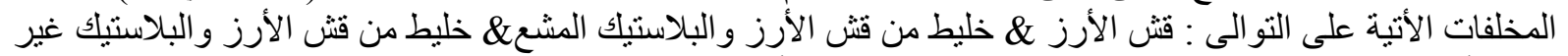

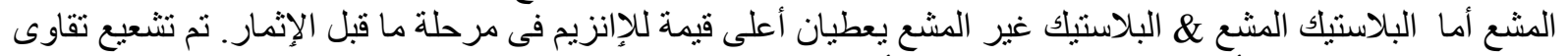

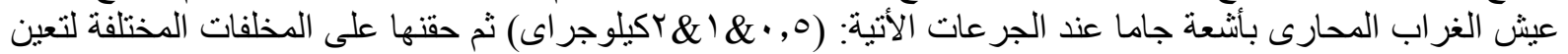

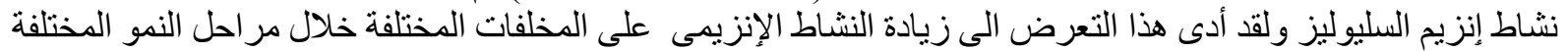

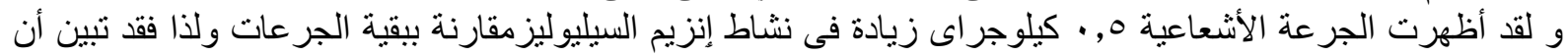

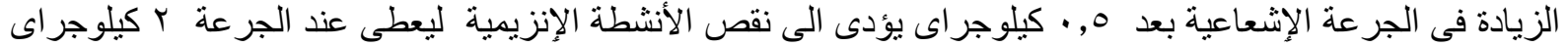

